Copyright (C) 2021 by Cherkas Global University

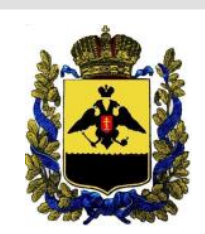

Published in the USA

Bylye Gody

Has been issued since 2006.

E-ISSN: $2310-0028$

2021. 16(4): 1624-1637

DOI: $10.13187 /$ bg.2021.4.1624

Journal homepage:

https://bg.cherkasgu.press

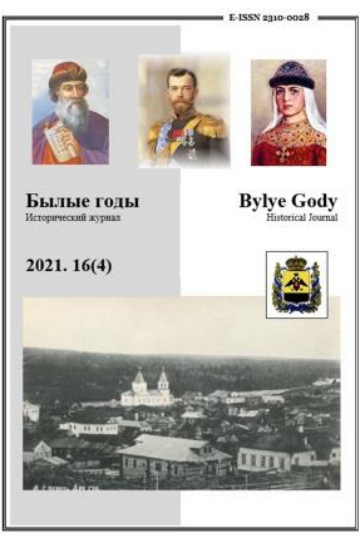

\title{
On the Issue of Reforming Public Education in the Russian Empire
}

Olga I. Artemenko a, Svetlana P. Anzorova ${ }^{\text {b , * }}$, Svetlana A. Moskvicheva c, Daria V. Petrukhina a

a Russian Presidential Academy of National Economy and Public Administration, Russian Federation

b Synergy University, Moscow, Russian Federation

c Peoples' Friendship University of Russia (RUDN), Moscow, Russian Federation

\begin{abstract}
The work shows the objective nature of the pre-revolutionary reform of school education, dictated by the need to educate the population of Russia as an indispensable condition for the democratic restructuring of society and its economic development. The main historical reason that caused the emergence of the general school as a new institution of socialization, in addition to the existing ones - the family and the church, was modernization. The school of the church parish was focused on teaching children literacy in order to independently read the Bible translated into their native languages, for religious and moral education of students, ensuring the unity of faith. And this meant the universal, extraterrestrial nature of such a school. In the future, as the most important socio-cultural institution of society, as the institution of state policy, the school receives its main tasks from the state in order to modernize society, providing universal compulsory primary education. At the end of the XIX century (1906), political parties and sociopedagogical organizations of Russia proposed the introduction of universal primary education. However, in pre-revolutionary Russia, such a bill was never adopted. Soviet power inherited $73 \%$ of the population (over 9 years old) elementary illiteracy.
\end{abstract}

Keywords: school, reform, pre-revolutionary Russia, society, modernization, literacy, financing, universal compulsory primary education.

\section{1. Введение}

Одним из базовых процессов модернизации общества является реформирование системы образования, наряду с другими фундаментальными процессами. Именно степень развития системы образования обеспечивает уровень грамотности, образованности населения, формирует определенные качества личности, что способствует экономическому и социальному росту. В этом контексте в государстве, имеющем полиэтнический состав, исторически сформированный не мигрантами, а местными жителями, особого внимания заслуживают вопросы организации образования для народов, населяющих Российскую империю, и реализации их в рамках доктрины государственно-охранительного просвещения.

Результатом реорганизации всего школьного образования Российской империи предполагалось повышение грамотности многонационального населения, получение детьми, независимо от национальной принадлежности, как минимум начального образования.

\section{2. Материалы и методы}

Выявление документов для статьи определялось стремлением авторов представить широкий спектр мнений государственных, политических, общественных, национальных деятелей по стратегически важной проблеме - гармонизации государственных и национальных интересов в области образования,

${ }^{*}$ Corresponding author

E-mail addresses: anzorova@inbox.ru (S.P. Anzorova) 
нашедших отражение в реформировании этой сферы Российской империи. Реализация данной задачи требовала комплексного выявления как архивных, так и опубликованных источников.

В Российском государственном историческом архиве (РГИА), Государственном архиве РФ (ГАРФ), Российской государственной библиотеке (РГБ) просмотрены фонды Министерства народного просвещения и его департаментов, стенографические отчеты Государственной Думы, личные фонды министров просвещения (В.Г. Глазова, П.М. фон Кауфмана, И.И. Толстого, А.Н. Шварца). Так, например, Письмо министра внутренних дел П.А. Столыпина министру народного просвещения А.Н. Шварцу с предложением созвать межведомственное совещание по вопросу о постановке школьного образования для инородческого населения. 30 января 1909 г. (Письмо министра, 1909: РГИА. Ф. 821. Оп. 10. Д. 517. Л. 3-6); Из Доклада председателя особого совещания по вопросам образования восточных инородцев тайного советника А.С. Будиловича министру народного просвещения В.Г. Глазову с изложением хода работы и решения совещания. 15 августа 1905 года. Труды Особого совещания по вопросам образования восточных инородцев (Из Доклада председателя особого совещания, 1905: VI-IX, XII-XIV, XXI-XXII, XXXVI-XXXIX, XL-XLII, LI-LII, LIII); Воспоминания И.И. Толстого (Воспоминания И.И. Толстого, 1916: Отдел рукописей РГБ. Ф. 218. К. 1290. Л. 149-156); Доклад министра народного просвещения Д.А. Толстого «О мерах с образованием населяющих Россию инородцев» (Толстой, 1870: Отдел рукописей РГБ, 1890: 15551566); Распоряжение Временного правительства «Об объединении в целях введения всеобщего обучения учебных заведений разных ведомств в ведомство Министерства народного просвещения» (Распоряжение Временного правительства, 1917: 1014); Справка особого отдела Департамента полиции «О деятельности панисламистов в империи» вице-директору Департамента полиции. 16 марта 1910 (Справка особого отдела, 1910: ГАРФ. Ф. 102. Оп. ДОО 1910. Д. 74. Л. 38-46об.); Докладная записка директора Департамента духовных дел Министерства внутренних дел А. Харузина директору Департамента народного просвещения С.И. Анциферову с предложением схемы вопросов для междуведомственного совещания по вопросу образования инородцев (Докладная записка, 1910: РГИА. Ф. 846. Оп. 1. Д. 165. Л. 1-13); Переписка министра народного просвещения Л.А. Кассо и председателя Совета министров В.Н. Коковцова по вопросу о некоторых изменениях в Правилах 1 ноября 1907 года о начальных училищах для инородцев (Переписка Министра, 1913: РГИА. Ф. 773. Оп. 227. Д. 114. Л. 118-126).

Циркуляр Министерства народного просвещения «Об утверждении Правил о начальных училищах для инородцев восточной и юго-восточной России» (Циркуляр Министерства народного просвещения, 1906: 267-274); Закон, одобренный Государственным Советом и Государственной Думой «Об отпуске средств» (Закон «Об отпуске средств», 1908: 996).

В научном архиве Российской академии образования (РАО) документы выявлялись в коллекции исторических документов и фондах видных педагогов, общественных деятелей В.П. Вахтерова, Н.В. Чехова и др. (Вахтеров, 1999: 77)

Перечисленные материалы впервые вводятся в научный оборот и помогают восстановить этапы становления образования в Российской империи. Данные разнохарактерных источников, дополняя и уточняя друг друга, помогают восстановить достаточно цельную картину становления народного образования в Российской империи, содержат ценный материал для изучения вопросов развития образования дореволюционного периода.

Использованный авторами принцип историзма позволяет учитывать особенности изучаемого дореволюционного периода и дает понимание причинно-следственных связей тех или иных событий, в большей степени определяющих экономическое развитие государства. Принцип объективности предполагает использование только неискаженных и проверенных фактов и источников. Такой метод позволил рассматривать народное образование Российской империи, ее реформирование во всей совокупности исторического развития.

Принцип историзма помог изучить события и явления дореволюционного периода, исторические факты с точки зрения современников той эпохи (Филимонов, 1893: 4-9).

При решении конкретных исследовательских задач использовались сравнительноисторический, биографический, синхронный и диахронный методы.

\section{3. Обсуждение}

Начиная с середины XVIII века, особое внимание отводилось вопросам образования мусульманских народов. Практически в России основной системой народного просвещения мусульманских народов была мусульманская конфессиональная школа: почти при каждой мечети действовали начальные школы (мектебы), в городах и крупных селах - медресе. В 1708 году была образована Казанская губерния и Казань стала одним из важных административных, промышленных и образовательных центров Российской империи. Как следствие этих процессов, началась насильственная христианизация коренных народов Поволжья. В середине XIX века возникла необходимость создания особой модели школьного образования.

Исследованиями, посвященными реформированию системы народного образования Российской империи, занимались многие авторы в различные периоды становления

$$
-1625-
$$


государственности. В дореволюционный период - это работы Д.Ф. Филимонова (Филимонов, 1893: 12) и епископа Никанора о Николае Ивановиче Ильминском (Епископ Никанор, 1892: 93-94) и др. В них раскрываются методология и методы реформирования системы школьного образования, разработанные Николаем Ивановичем Ильминским. Предложенная им организация образования для инородцев легла в основу государственной политики Российской империи и практически реализовывалась до 1990 года с небольшими изменениями.

Такой длительный срок определялся тем, что «сохранялись естественные процессы и потенциал, которые противостояли распаду веками складывавшейся государственности, содержащей в себе особые, целостные системные свойства от многих, вошедших в ее состав культур» (Артеменко, 2011: 124-131).

Предложенные Н.И. Ильминским методы организации обучения способствовали повышению уровня грамотности нерусского населения восточной части России. В основе его системы лежит «дело умственного, религиозного и нравственного воспитания» нерусских народов Поволжья путем использования родного языка, местного быта и обычаев. О необходимости реформы медресе отмечал в своих работах в 1862 году и Х. Фаизханов (Реформа медресе. Ислах мадарис, 1862: 54). В проекте реформ мусульманского конфессионального образования, подготовленном Х. Фаизхановым, была сделана первая системная попытка создания особой модели образования с учетом необходимости изучения не только восточных языков, но и русского. Он всерьез размышлял о европеизации обучения в татарских школах, понимая необходимость обновления консервативного мусульманского сообщества. Проблемы образования инородческого населения Казанского царства до 1762 года описывались в работе «Инородческое население прежнего Казанского царства в новой России до 1762 г.» (Фирсов, 1869: 448). К 1905 году только в Казанской губернии значительная часть населения (50 тыс.) обучалась в 845 мектебах и медресе. К 1913 г. их количество увеличилось до 967 и обучалось в них около 80 тыс. учащихся.

Значение системы образования в экономическом развитии государства в дореволюционный период отмечалось в работе «Народное образование в России» (Левассера, 1899), в которой на примере цивилизованных стран показывалась значимость процессов реформирования образования, способствующего развитию деятельностной личности. Создание условий для обеспечения права на образование является обязанностью государства, поскольку через него осуществляется право на достоинство, на развитие потенциала человека, что восходит еще к идеям Л. Дюги, который писал: «Мало того, чтобы государство не приносило никакого ущерба своими законами свободному развитию деятельности личности, нужно еще, чтобы каждый мог развивать свою личную деятельность» (Дюги, 1908: 911).

К 1914 в Российской империи функционировало свыше 1 тыс. земских и около 50 городских начальных школ. Кроме того, действовало более 400 церковно-приходских школ. Охват детей начальным образованием составлял более 50 \%. Одновременно с этим расширялась сеть министерских русско-национальных школ, инородческих школ, в образовательно-просветительской основе которых лежала миссионерская система Н.И. Ильминского. Она предусматривала использование в образовательной деятельности родных языков и культур инородцев. Миссионерские учебные заведения способствовали формированию национальной интеллигенции коренных народов региона и развитию их образования, интегрируя в российский социум.

В советский период для процесса изучения образования дореволюционного периода было характерно несколько направлений: обучение и воспитание в национальных школах (Волков, 1986: 105); актуальные вопросы преподавания русского и родного языков в национальной школе (Черников, 1973: 224); исследование среднего образования в России в XIX веке (Днепров, 1981: 90); история средней школы (Константинов, 1947: 247); грамотность и образование в дореволюционной России (Богданов, 1964: 195); анализ существовавших до 1917 г. форм образования (Звягинцев, 1918: 88); изучение становления женского образования в России: (Львов, 1956: 39-48); история женского образования в России (Филиппова, 1963: 209-218).

В современном российском дискурсе основными трендами выступают также исследование вопросов образования и грамотности населения в дореволюционный период: неизученные проблемы образования и педагогики дореволюционной России (Днепров, 2014: 87); развитие грамотности населения и модернизация общества (Кузьмин, 2008: 120-126); становление и развитие системы образования и борьба с неграмотностью в России в XVIII - первой половине XX веков: тенденции, препятствия, итоги (Зубов, 2018: 7); становление отечественного педагогического образования и вклад династии Романовых в его развитие (Джуринский, 2016: 8-38); роль коллегиального попечительства в развитии общего образования в дореволюционной России (Крюкова, 2014: 30-35).

Работы, посвященные образованию инородцев в Российской империи, делятся на два основных блока: первый - труды о национальных школах и просвещении нерусских народов, такие как «Национальная школа России: традиции и современность в контексте модернизации» (Кузьмин, 1993: 252); «Система просвещения нерусских народов в период контрреформ Александра III» (Феонычев, 2019: 399-404); «Вопросы просвещения мусульманских народов в деятельности органов местного самоуправления Южного Урала в 1870-1917 гг. (Петрич, 2019: 30); «Этнопедагогические 
аспекты концепций развития национальной школы - исторический экскурс» (Стручков, 2021: 37-40); «Реализация политики в области образования для нерусских народов в дореволюционной России на рубеже XIX-XX вв.» (Иванова, 2016: 243-250); «Просвещение нерусских народов Поволжья во второй половине XIX - начале XX века (историография проблемы)» (Анохина, 2006: 38).

Второй блок: изучение наследия и роли Н.И. Ильминского в организации образования нерусских народов - «О роли Н.И. Ильминского в просвещении народов Поволжья в конце ХІХ начале XX века» (Пупышев, 2019: 80-83); «Деятельность сторонников Н.И. Ильминского в поддержку системы просвещения нерусских народов Востока России в начале XX века» (Павлова, 2017: 121-128); «Научные труды Н.И. Ильминского по вопросам просвещения нерусских народов» (Павлова, 2019, 112-119); «Научные труды Н.И. Ильминского по вопросам просвещения нерусских народов» (Павлова, 2020: 150-157).

\section{4. Результаты}

\section{Общие подходы к реформированию образования в Российской империи}

Анализ прошедшего позволяет понять общие подходы к реформированию образования в Российской империи.

На определенном этапе развития общества потенциал традиционных исторических институтов социализации - семьи и церкви - оказывается для этих процессов недостаточным (Церковные школы, 1903-1916: 138), и тогда рождается еще один институт социализации, ранее не существовавший - всеобщая начальная школа. Нужно отметить, что философия Просвещения (Кларин, 1989: 416) постулирует первостепенное (наряду с наукой) значение просвещения как фактора общественного прогресса.

В эти процессы модернизации общества, когда требовалась реализация всеобщего обучения, Россия была вовлечена во второй половине XIX века. Первая российская перепись 1897 года (Первая перепись населения, 1897) показала всего 21,1 \% грамотных среди населения от 9 до 49 лет.

В России доля учащихся в 1905 г. составляла всего 3,5 \% от всего населения страны. По грамотности в этот исторический период Россия была на последнем месте среди европейских государств: в большинстве из них данный показатель колебался от 12 до 17 \% (Кузьмин, 1993: 227-230).

В дореволюционной России (с конца XVIII до начала XX вв.) единого руководства начальным (как и средним) образованием не было, практически не было единой системы образования. Образование курировали сразу несколько ведомств: наряду с Министерством народного просвещения, это были Святейший правительствующий синод, Военное министерство, Министерство внутренних дел и т.д.

К началу 1897 г. в стране действовало 78,7 тысяч начальных общеобразовательных учебных заведений. Из них в ведении Святейшего синода находилось 34,8 тыс. (44 \%), Министерства народного просвещения - 32,7 тыс. (42 \%), Военного министерства - 10,3 тыс. (13 \%) и т.д. (Днепров, 1985: 17).

Наибольшие вливания государство делало в так называемые «министерские», или образцовые, училища, находившиеся в исключительном ведении Министерства народного просвещения, а также в школы на национальных окраинах и в местностях с «инородческим» населением. Такой подход диктовался политическими соображениями. Школы для инородцев поволжских мусульман государство финансировало почти на 48 \%, а еврейские начальные - почти на 52 \%. Наряду с государством, в расходах на содержание министерских образовательных организаций принимали участие крестьянские общества. За период с 1889 по 1893 гг. ежегодно в среднем возникало 1280 начальных школ и лишь 475 училищ. В таком отношении к начальной школе русскоязычного населения была известная (хоть и небезупречная) логика: подавляющее большинство подданных Дома Романовых составляли крестьяне. Однако к концу XIX века стал несомненным промышленный подъем, который переживала Россия, что потребовало не только притока новых, желательно грамотных работников на заводы и фабрики, но и развития сельского хозяйства, которое грозило остаться утопией без овладения крестьянской массой элементарной грамотностью. А ее уровень в стране, по переписи 1897 г., едва превышал 20 \% (Население России последние 100 лет, 1998: 222). Кроме того, идея интеграции национальных окраин империи, ставшая центральной для политической элиты страны с начала 1860-х гг., предполагала повышение культурного уровня большинства населения страны. Нужно отметить, что русские вовсе не являлись самым образованным народом империи (читать умели чуть более $29 \%$, для сравнения: среди финнов этот показатель составлял более 98 \%). Они заметно отставали в этом от некоторых народов России, кроме украинцев и белорусов, которые в то время тоже считались частью единого русского народа (Левассера, 1899: 264).

Без передачи ценностей аристократической культуры XIX века крестьянским массам говорить о создании современного государства не приходилось.

Первые изменения общей школьной реформы для всего населения

Подвижки реформирования школы в России в положительном направлении, пусть и весьма скромные, начались с 1897 года, когда финансирование начального образования увеличилось на

$$
-1627 \text { - }
$$


250 тысяч рублей. Расходы в этой сфере возрастали ежегодно: в общей сложности с 1896 по 1903 годы - более чем в два раза. В управление Н.П. Боголепова (1898-1901) внимание ведомства просвещения стало смещаться с окраин империи на великорусский центр. Распределение новых средств начали связывать с численностью населения учебных округов и долей детей школьного возраста, оставшихся без образования. Этот процесс положил начало всеобщему образованию. Заслуга перевода этого вопроса из области благих, абстрактных пожеланий в практическое русло принадлежит земствам (Чарнолуский, 1910: 56-57), которые придавали большое значение развитию народного образования. В 1890-1907 годы «школьный» бюджет всех земств вырос в 3,6 раза, а его доля в общеземском бюджете - в 1,3 раза.

Планировалось, что всеобщее обучение, по примеру стран Запада, должно охватить детей и подростков в возрасте от 7 до 17 лет, то есть 15 \% населения империи, но к таким расходам государство не было готово. В 1894 г. выдающийся педагог В.П. Вахтеров предложил более реалистический вариант: ориентироваться пока на контингент детей 8-11 лет, причем в сельской местности - только на 20 \% девочек. В этом направлении и стала в дальнейшем развиваться начальная школа (Распоряжение Временного правительства, 1917: 1014). Именно земский тип школы был признан государством основой для реформы, что связано прежде всего с тем, что он требовал меньшего финансирования, и с наличием активной земской интеллигенции, готовой работать на этом поприще не покладая рук.

Земские школы некоторых уездов Министерство народного просвещения субсидирует с 19011903 годов, где по условиям, выдвинутым ведомством, эти деньги шли на содержание учителей. «Нормальным» признавался оклад в 360 рублей в год, тогда как среднее жалованье земского учителя составляло 276 рублей, что полностью должно было освободить от расходов на школу сельские общества (Сучков, 1995: 62-77).

Таким образом, государство впервые обозначило введение всеобщего начального обучения в качестве своей приоритетной задачи. В1904 г. данный вопрос был поднят, но русско-японская война помешала практическим шагам по его воплощению.

Первоочередной государственной задачей всеобщее обучение стало только после революции 1905 г. Важная роль в этом принадлежит министрам народного просвещения графу И.И. Толстому (1905-1906) и П.М. Кауфману (1906-1908) (Воспоминания И.И. Толстого, 1870). Кроме того, всеобщее обучение являлось одной из важнейших составляющих программы реформ премьерминистра П.А. Столыпина, делавшего ставку на создание широкого слоя мелких и средних собственников в деревне, который, конечно же, должен был быть грамотным. Несмотря на то, что «либералов» Толстого и Кауфмана в дальнейшем сменили «реакционеры», задача перехода на всеобщее образование (проект закона) обсуждалась третьей Государственной Думой.

Так как значимость проекта закона была очень велика, мы приводим некоторые выдержки его содержания:

- всем детям обоего пола должна быть предоставлена возможность, по достижении школьного возраста, пройти полный курс обучения в правильно организованной школе;

- забота об открытии достаточного числа училищ соответственно числу детей школьного возраста лежит на учреждениях местного самоуправления, а также все вопросы финансирования относятся на местные источники.

Закон так и не был принят, но, тем не менее, деятельность Министерства народного просвещения в данной сфере с 1908 года продолжалась. Был принят закон об увеличении субсидий начальной школе, предусматривавший ежегодный дополнительный отпуск 6,9 миллиона рублей для выплаты жалованья учителям в размере 390 рублей (в расчете 1 учитель на 50 учеников), для постройки и оборудования училищных зданий (Закон «Об отпуске средств», 1908).

\section{Реформы образования инородцев в Российской империи}

Организация образования «инородческого» и «иноверческого» населения Российской империи в реформировании представляла собой отдельную сложную задачу. Политика центральной власти в этом вопросе не была единой ни в отношении разных национальных окраин Российской империи, ни для различных внутренних областей России. Это касалось как целей образования, в том числе проектов русификации инородческого населения в векторе интеграции, так и вопросов, связанных с выбором языка образования, которым мог быть как родной язык учащихся, так и русский. В области просвещения и образования нерусских подданных восточных окраин империи и центральной России создание и модернизация именно начальной школы являлись первоочередными задачами, на решение которых были направлены силы как правительства, так местного самоуправления и национальной интеллигенции. (Епископ Никанор, 1892: 93-94).

В организации образования нерусского населения Российской империи можно выделить два этапа: первый - с 1864 по 1906 гг., второй - с 1906 по 1917 гг. Для удобства анализа выделим следующие аспекты: идеологию в области образования, собственно образовательную политику и связанную с ней законодательную базу, а также планирование в области образования, то есть внедрение решений в жизнь (Фирсов, 1869: 37-38). 
Первый этап реформирования (1864-1906 гг.).

На первом этапе реформ в области начального образования инициатива и ведущая роль принадлежала государству. Это, безусловно, были реформы «сверху» для «более прочного сближения инородцев с коренным русским народом путем постепенного распространения между ними знания русского языка» (Толстой, 1870: Отдел рукописей РГБ, 1890: 1555-1566). Как представляется, речь здесь идет не столько об ассимиляции, сколько об интеграции нерусских народов в православие российского общества, культуру большинства, вставшего на путь демократических преобразований. Именно в этом смысле стоит толковать часто используемое в документах слово «обрусение». Политика просвещения в полной мере относилась и к русскому народу, но в данном случае она не встречала препятствий ни в виде языкового барьера, ни в виде конкурирующих систем традиционного религиозного образования (мектебов и медресе при мечетях), как это было в случае татарского населения.

Начиная с 1864 года, выходит целый ряд положений Министерства народного просвещения, регламентирующих организацию образования на уровне начальной школы (14 июля 1864, 26 марта 1870, 25 мая 1874).

В положении 1864 года о начальных народных училищах регламентируется их общая деятельность, 1870 года - описываются конкретные правила образовательной деятельности школ для инородцев и в 1874 г. - принимаются уточненные правила организации образовательной деятельности начальных народных училищ.

По правилам 1870 года для нерусского населения создается особый тип школы, получивший называние русско-инородческие училища. Согласно этим «Правилам», отдельно создавались училища для христианизированных народов и училища для «татар-магометан» Казанского, Одесского учебных округов и Крыма. В русско-инородческих училищах языком обучения был русский. Данный тип училищ должен был составить конкуренцию и заменить традиционные мектебы, однако этого не произошло. Во-первых, такие училища были малочисленны, так для почти 60 ооо татарского населения Нижегородской губернии была открыта в 1871 году по инициативе И.Н. Ульянова одна русско-татарская школа (Сабиров, 1982). Однако и она не имела популярности, не пользовалась доверием местного населения и была закрыта в 1915 году.

В 6о-е годы начинается реформаторское движение среди самого татарского населения. В 1862 г. вышла работа Х. Фаизханова «Реформа медресе» (Фаизханов, 1862), где уже были изложены все основные идеи, получившие развитие в рамках реформаторского движения джадидизм и воплотившиеся в так называемых «новометодных» школах И. Гаспринского. Х. Фаизханов и представители джадидизма выступали за образование на родном языке при обязательном преподавании русского языка. Новометодные школы, первая из которых была открыта в Бахчисарае в 1884 году, были основаны на последних достижениях педагогики и психологии того времени. В них широко использовались звуковая методика обучения чтению и методика А.О. Чернявского, которые являлись передовыми для своего времени и давали хорошие результаты, но были дорогими в содержании.

Результаты первого этапа реформы образования инородцев Российской империи, возможно, нельзя назвать впечатляющими, так как до сколь-нибудь значительного охвата начальным образованием было еще очень и очень далеко. Однако в это время были опробованы модели земских и частных школ, был наработан педагогический опыт преподавания для нерусских учащихся и, как следствие, появилось ясное понимание проблемных зон в данной области.

Второй этап реформирования (1906-1917)

Второй этап связан с реформами после революционных событий 1905 года. В области законодательной деятельности следует перечислить документы Министерства народного просвещения 1906, 1907 и 1913 годов, касающиеся организации образовательной деятельности для инородцев и получивших название «Правил...». Их целями было “содействовать нравственному и умственному развитию инородцев и таким образом открывать им путь к улучшению их быта, а с другой стороны - распространению между ними знания русского языка и сближения их с русским народом на почве любви к общему отечеству» (Правила о начальных училищах, 1913: 79).

Пункт 3 данных Правил определял, что «орудием первоначального обучения для каждого племени должно быть природное его наречие» (Правила о начальных училищах, 1913: 79). Это было важнейшее дополнение, свидетельствующее о смене идеологии в области начального образования.

В заключении к этому разделу нужно сказать следующее. В период реформ с 1864 по 1917 годы шла напряженная работа по определению оптимальной модели «инородческой» школы, причем пристальное внимание уделялось анализу конкретных ситуаций, что позволило учитывать специфику каждого региона. Образовательная идеология первого периода реформ (1864-1906) определялась властью, была направлена на «обрусение» нерусского населения империи, которое правильно было бы понимать в современной терминологии не как ассимиляцию, а как инкультурацию и интеграцию в общероссийский социум. Реформа проходила на фоне широкой просветительской деятельности как внутри самих народов, в частности движения джадидизма, так и на фоне миссионерской деятельности церкви (труды Братства Святого Гурия), при поддержке демократически настроенной интеллигенции.

$$
-1629-
$$


Во второй период, начиная с 1906 года, происходит демократизация как образовательной идеологии, так и образовательной политики, что нашло выражение среди прочего в признании приоритета светской школы и необходимости обучения в начальной школе на родном языке.

\section{5. Заключение}

Таким образом, вопреки реализации образовательных реформ Российская империя закончила свое существование, так и не решив проблему введения всеобщего (а уж тем более обязательного) начального образования.

С большой долей уверенности можно предположить, что, не будь войны и революций, обязательное всеобщее обучение в Российской империи было бы введено к началу 1920-х годов. Это предположение подтверждается проектами законов, которые регулярно, с 1911 по 1916 годы, обсуждались на уровне законодательной власти (Государственной Думы) Российской империи. Они предусматривали, в частности, обязательность начального образования; минимум ежегодного повышения пособия школам, направляемого Министерством народного просвещения (10 миллионов рублей); явочный, а не разрешительный порядок открытия училищ; также упрощенную процедуру назначения учителей; расширение прав органов самоуправления в формировании училищных советов и выработке программ; введение в учебную программу кратких курсов геометрии, географии, истории России, природоведения. Нужно отметить, что положения образовательной реформы Российской империи в дальнейшем были частично реализованы.

\section{6. Благодарности}

Работа подготовлена в рамках выполнения научно-исследовательской работы государственного задания РАНХиГС.

\section{Литература}

Анохина, 2006 - Анохина И.А. Просвещение нерусских народов Поволжья во второй половине XIX - начале XX века (историография проблемы) // МИТС-НАУКА: международный научный вестник: сетевое электронное научное издание. 2006. № 5. С. 39-44.

Артеменко, 2011 - Артеменко О.И. Удовлетворение этнокультурных образовательных потребностей народов России: государственность, этническая идентичность // Eвразийский юридический журнал. 2011. № 8 (39). С. 124-131.

Богданов, 1964 - Богданов И.М. Грамотность и образование в дореволюционной России и в CССР: историко-статистические очерки. М.: Статистика, 1964. 195 с.

Вахтеров, 1999 - Вахтеров В.П. Всеобеее начальное обучение. Москва, 1999. 77 с.

Волков, 1986 - Волков Г.Н. Нравственное воспитание учащихся IV-VIII классов сельской национальной школы: Пособие для учителя. М.: НИИ нац. школ, 1986. 105 с.

Ганелин, 1950 - Ганелин Ш.И. Очерки по истории средней школы в России второй половины ХIX века / Под ред. Н.Г. Казанского. М.: Учпедгиз, 1950. 274 с.

ГАРФ - Государственный архив Российской Федерации.

Демидов, 1914 - Демидов П.А. Об улучшении татарских школ в Нижегородской губернии. Доклад Нижегородской губернской земской управы 50-му очередному губернскому земскому собранию 1914 г. [Электронный ресурс]. URL: http://www.idmedina.ru/books/school-book/1302 (дата обращения: 19.07.21).

Джуринский, 2016 - Джуринский A.H. Становление отечественного педагогического образования и вклад династии Романовых в его развитие // Художественное образование в дореволюционной России // Сборник научных трудов / Сост. В.П. Демин, Е.М. Акишина, Д.В. Поль. Российская академия образования, Отделение образования и культуры. М.: ФГБНУ "ИХОиК РАО". 2016. С. 8-38.

Днепров, 1981 - Днепров Э.Д. Советская историография отечественной школы и педагогики (1913-1977 гг.): Проблемы, тенденции, перспективы. М.: АПН СССР, НИИ ОП, 1981. 90 с.

Днепров, 1985 - Днепров Э.Д. О разработке методологических, историографических и источниковедческих проблем истории педагогики // Школа России накануне и в период революции 1905-1907 гг. М., 1985. С. 59-73.

Днепров, 2014 - Днепров Э.Д. Образование и педагогика дореволюционной России: неизученные проблемы. Справочное пособие для исследователей. М.: Мариос. 2014. 87 с.

Доклад об улучшении татарских школ, 1913 - Доклад об улучшении татарских школ в Нижегородской губернии. Н. Новгород, 1913. С. 3-18.

Дюги, 1908 - Дюги Л. Конституционное право. Общая теория государства. Москва: Типография Товарищества И.Д. Сытина. 1908. 911 с.

Епископ Никанор, 1892 - Епископ Никанор. Николай Иванович Ильминский (Ильминский Н.И. Избранные места из педагогических сочинений). Казань, 1892. С. 93-94.

Закон «Об отпуске средств», 1908 - Закон, одобренный Государственным Советом и Государственной Думой «Об отпуске средств». 6 июля 1908 г. СУ 1908. Ст. 996. 
Звягинцев, 1918 - Звягинцев E.A. Полвека земской деятельности по народному образованию. 2-е изд. М., 1918. 88 с.

Зубков, 2012 - Зубков И.В. Расписание перемен: Очерки истории образовательной и научной политики в Российской империи - СССР (конец 1880-х - 1930-е годы). М.: Из-во «Новое литературное обозрение». 2012.

Зубов, 2018 - Зубов В.В. Становление и развитие системы образования и борьба с неграмотностью в России в XVIII - первой половине XX вв.: тенденции, препятствия, итоги // Гуманитарный вестник. 2018. № 12 (74). С. 7.

Иванова, 2016 - Иванова И.П. Реализация политики в области образования для нерусских народов в дореволюционной России на рубеже XIX-XX вв. (на примере Чувашского края) // XX век в истории России. Гражданственность и патриотизм народа в годы великих потрясений и мирного строительства / Сборник статей. Чебоксары: Чувашский государственный университет им. И.Н. Ульянова. 2016. С. 243-250.

Из Доклада председателя особого совещания, 1905 - Из Доклада председателя особого совещания по вопросам образования восточных инородцев тайного советника А.С. Будиловича Министру народного просвещения В.Г. Глазову с изложением хода работы и решения совещания. 15 августа 1905 года. Труды Особого Совещания по вопросам образования восточных инородцев. СПб., 1905. C. VI-IX, XII-XIV, XXI-XXII, XXXVI-XXXIX, XL-XLII, LI-LII, LIII.

Ислах мадарис, 1862 - Ислах мадарис - реформа просвещения. СПб., 1862. 54 с.

Кларин, 1989 - Кларин В.М., Каменский Я.А., Локк Д., Руссо Ж.-Ж., Песталоцци И.Г. Педагогическое наследие. М.: Педагогика, 1989. 416 с.

Константинов, 1947 - Константинов Н.А. Очерки по истории средней школы (Гимназии и реальные училища с конца XIX века до Февральской революции 1917 года). М.: Госучпедиздат. 1947. $247 \mathrm{c}$.

Крюкова, 2014 - Крюкова А.А. Роль коллегиального попечительства в развитии общего образования в дореволюционной России // Гуманизация образования. 2014. № 6. С. 30-35.

Кузьмин, 1993 - Кузьмин М.Н. Национальная школа России: традиции и современность в контексте модернизации // Труды института национальных проблем образования. М.: ИНПО. 1993. № $1.252 \mathrm{c}$.

Кузьмин, 1993 - Кузъмин М.Н. Российская педагогическая энциклопедия: Т. 1. М.: БРЭ. 1993. C. 227-230.

Кузьмин, 2008 - Кузьмин М.Н. Развитие грамотности населения и модернизация общества // Мир образования - образование в мире. 2008. № 2 (30). С. 120-126.

Кузьмин, 2015 - Кузъмин М.Н. Российская модернизация и некоторые проблемы историзма человека / Форум педагогического мастерства. Учебно-методическое пособие по материалам Всероссийского мастер-класса учителей родных, включая русский, языков 2011-2013 гг. / Под общ. ред. О.И. Артеменко. М.: ИНПО. 2015. С. 7-12.

Кулбахтина, 2017 - Кулбахтина А.З. Политический курс государства в мусульманском образовательном сегменте на рубеже XIX-XX вв.: задачи, проблемы, решения // Образование $u$ духовная безопасность. 2007. № 1. С. 56-64.

Лебедева, 1988 - Лебедева Р.Л. Социальное положение учителей России в канун Великой Октябрьской социалистической революции // Педагогическая интеллигенция: социальнополитические проблемы / Межвуз. сб. научн. трудов Ленин. гос. пед. ин-та им. А.И. Герцена. Л., 1988. C. 56-61.

Левассера, 1899 - Левассера Э. Народное образование в России // Народное образование в цивилизованных странах. Издание О.Н. Поповой / Ред. Г. Фальборка и В. Чарнолуского. СПб., 18981899. T. 2. 1899. 264 c.

Львов, 1956 - Львов К.И. Борьба П.Ф. Лесгафта за женское образование // Советская педагогика. 1956. № 6. С. 39-48.

Население России последние 100 лет, 1998 - Население России за 100 лет (1897-1997). Статистический сборник. М.: Госкомстат России. 1998. 222 с.

Никольский, 1898 - Никольский Н.M. Николай Иванович Ильминский. Очерк его жизни и деятельности. СПб., 1898. 108 с.

О введении всеобщего..., 1995 - О введении всеобщего начального обучения // Законотворчество думских фракций. 1906-1917 годы: Документы и материалы. М., 2006.

ОР РГБ - Отдел рукописей Российской государственной библиотеки.

Ососков, 1982 - Ососков А.В. Начальное образование в дореволюционной России (1861-1917). М.: Просвещение. 1982. 208 с.

Очерк развития, 1914 - Очерк развития земского хозяйства. Н. Новгород: Типолит. «Нижегородское печатное дело». 1914. VI. 228 с.

Павлова, 2016 - Павлова А.Н. Деятельность сторонников Н.И. Ильминского в поддержку системы просвещения нерусских народов Востока России в начале XX века // XX век в истории России. Гражданственность и патриотизм народа в годы великих потрясений и мирного 
строительства / Сборник статей. Чебоксары. Чувашский государственный университет им. И.Н. Ульянова. 2016. С. 312-317.

Павлова, 2017 - Павлова А.Н. Опубликованные и документальные материалы по истории развития школьного образования нерусских народов среднего Поволжья в 70-90-х годах XIX века // Вестник Чувашского университета. 2017. № 2. С. 121-128.

Павлова, 2019 - Павлова А.Н. Научные труды Н.И. Ильминского по вопросам просвещения нерусских народов // Вестник Чувашского университета. 2019. № 2. С. 112-119.

Павлова, 2020 - Павлова А.Н. Государственная национальная политика в области образования народов Поволжья и Приуралья во второй половине XIX - начале XX века // Исторический опьт нациестроштельства и развития национальной государственности чувашского народа / Материалы Всероссийской научно-практической конференции. Чебоксары: Чувашский государственный институт гуманитарных наук. 2020. С. 150-157.

Первая перепись населения - Первая перепись населения в России в 1897 году. [Электронный pecypc]. URL: https://istoriarusi.ru/imper/pervaya-perepis-1897.html (дата обращения: 29.10.2021).

Петрич, 2019 - Петрич Л.В. Вопросы просвещения мусульманских народов в деятельности органов местного самоуправления Южного Урала в 1870-1917 гг. И.З. Шаяхметова // Электронный научно-образовательный журнал «История». 2019. № 8 (82). С. 30.

Правила о начальных училищах, 1913 - Правила о начальных училищах для инородцев: Утвержденные Министерством народного просвещения 05.06.1913 г. Ильминский Н.И. О системе просвещения инородцев и о Казанской центральной крещенотатарской школе. Казань, 1913. 79 с.

Пупышев, 2019 - Пупышев И.В. О роли Н.И. Ильминского в просвещении народов Поволжья в конце XIX - начале XX века // Парадигмы российской истории сквозь призму биографистики / Сборник трудов Всероссийской научной конференции с международным участием. ФГБОУ ВО «Чувашский государственный университет им. И.Н. Ульянова». Чебоксары. Общество с ограниченной ответственностью «Издательский дом «Среда». 2019. С. 80-83.

Распоряжение Временного правительства, 1917 - Распоряжение Временного правительства «Об объединении в целях введения всеобего обучения учебных заведений разных ведомств в ведомство Министерства народного просвещения». 3 марта 1917 г. СУ. 1917. Ст. 1014.

Распоряжение Министерства народного просвещения, 1907 - Распоряжение Министерства народного просвещения «Об утверждении «Правил о начальных училищах для инородцев». 1 ноября 1907 г. № 11. С. 461.

РГИА - Российский государственный исторический архив.

Сабиров, 1982 - Сабиров С. Некоторые материалы из истории школьного образования татарских школ Пильненского района Нижегородской области. Записки краеведа. 1982. [Электронный ресурс]. URL: http://www.idmedina.ru/books/school-book/1305 (дата обращения: 19.10.21).

Спасский, 1900 - Спасский Н.A. Просветитель инородцев Казанского края Николай Иванович Ильминский. Самара, 1900. 132 с.

Стручков, 2021 - Стручков А.Г. Этнопедагогические аспекты концепций развития национальной школы - исторический экскурс // Социокультурное развитие в условиях трансформации образования / Сборник трудов Всероссийской научно-практической конференции. Якутск, 17 апреля 2021 года. Киров: Межрегиональный центр инновационных технологий в образовании. 2021. С. 37-40.

Толстой, 1870 - Доклад министра Народного Просвещения Д.А. Толстого «О мерах с образованием населяющих Россию инородцев» (1870). [Электронный pecypc]. URL: http://inporus.ru/14/ (дата обращения: 19.10.21).

Труды Особого Совещания, 1905 - Труды Особого Совещания по вопросам образования восточных инородцев. СПб., 1905. С. VI-IX. XII-XIV. XXI-XXII. XXXVIII-XXXIX. XL-XLII. LI-LII, LIII.

Фаизханов, 1862 - Фаизханов $X$. Реформа медреса (Ислах мадарис). Перевод И.Ф. Гимадеева. СПб., 1862. [Электронный ресурс]. URL: http://www.idmedina.ru/books/school-book/1297 (дата обращения: 19.10.21).

Феонычев, 2019 - Феонычев В.В. Система просвещения нерусских народов в период контрреформ Александра III // Аграрная наука и образование на современном этапе развития: опыт, проблемы и пути их решения. Ульяновск. Ульяновский государственный аграрный университет им. П.А. Столыпина. 2019. С. 399-404.

Филимонов, 1893 - Филимонов Д.Ф. О Николае Ивановиче Ильминском. Казань, 1893. 12 с.

Филиппова, 1963 - Филиппова Л.Д. Из истории женского образования в России // Bonросы истории. 1963. № 2. С. 209-218.

Фирсов, 1869 - Фирсов Н.А. Инородческое население прежнего Казанского царства в новой России до 1762 г. Казань. 1869. 448 с.

Церковные школы, 1903 - Церковные школы Российской империи. Статистические сведения. СПб., 1903-1916. 138 с. 
Циркуляр Министерства народного просвещения, 1906 - Циркуляр Министерства народного просвещения «Об утверждения Правил о начальных училищах для инородцев восточной и юговосточной России» 31 марта 1906 г. № 6-7. С. 267-274.

Чарнолуский, 1910 - Чарнолуский В.И. Земство и народное образование // Русская школа. 1910. № 9. С. 56-57.

Черников и др., 1973 - Черников Р.К., Сабаткоев Р.Б., Сукунов Х.X. Актуальные вопросы преподавания русского и родного языков в национальной школе / Сборник материалов науч.практ. конф. М.: Педагогика. 1973. 224 с.

\section{References}

Anokhina, 2006 - Anokhina, I.A. (2006). Prosveshchenie nerusskikh narodov Povolzh'ya vo vtoroi polovine XIX - nachale XX veka (istoriografiya problemy) [Enlightenment of non-Russian peoples of the Volga region in the second half of the XIX - early XX century (historiography of the problem)]. MITSNAUKA: mezhdunarodnyi nauchnyi vestnik: setevoe elektronnoe nauchnoe izdanie. 5: 39-44. [in Russian]

Artemenko, 2011 - Artemenko, O.I. (2011). Udovletvorenie etnokul'turnykh obrazovatel'nykh potrebnostei narodov Rossii: gosudarstvennost', etnicheskaya identichnost' [Meeting the ethnocultural educational needs of the peoples of Russia: statehood, ethnic identity]. Evraziiskii yuridicheskii zhurnal. 8(39): 124-131. [in Russian]

Bogdanov, 1964 - Bogdanov, I.M. (1964). Gramotnost' i obrazovanie v dorevolyutsionnoi Rossii i v SSSR: istoriko-statisticheskie ocherki [Literacy and education in pre-revolutionary Russia and the USSR: historical and statistical essays]. M.: Statistika, 195 p. [in Russian]

Charnoluskii, 1910 - Charnoluskii, V.I. (1910). Zemstvo i narodnoe obrazovanie [Zemstvo and public education]. Russkaya shkola. 9: 56-57. [in Russian]

Chernikov i dr., 1973 - Chernikov, R.K., Sabatkoev, R.B., Sukunov, Kh.Kh. (1973). Aktual'nye voprosy prepodavaniya russkogo i rodnogo yazykov v natsional'noi shkole [Topical issues of teaching Russian and native languages in the national school]. Sbornik materialov nauch.-prakt. konf. M.: Pedagogika. 224 p. [in Russian]

Demidov, 1914 - Demidov, P.A. (1914). Ob uluchshenii tatarskikh shkol v Nizhegorodskoi gubernii. Doklad Nizhegorodskoi gubernskoi zemskoi upravy 50-mu ocherednomu gubernskomu zemskomu sobraniyu 1914 g. [On the improvement of Tatar schools in the Nizhny Novgorod province. Report of the Nizhny Novgorod provincial zemstvo council to the 5oth regular provincial zemstvo assembly in 1914]. [Electronic resource]. URL: http://www.idmedina.ru/books/school-book/1302 (date of access: 19.07.21). [in Russian]

Dneprov, 1981 - Dneprov, E.D. (1981). Sovetskaya istoriografiya otechestvennoi shkoly i pedagogiki (1913-1977 gg.): Problemy, tendentsii, perspektivy [Soviet historiography of the domestic school and pedagogy (1913-1977): Problems, trends, prospects.]. M.: APN SSSR, NII OP, 90 p. [in Russian]

Dneprov, 1985 - Dneprov, E.D. (1985). O razrabotke metodologicheskikh, istoriograficheskikh i istochnikovedcheskikh problem istorii pedagogiki [On the development of methodological, historiographic and source study problems of the history of pedagogy]. Shkola Rossii nakanune i v period revolyutsii 19051907 gg. M. Pp. 59-73. [in Russian]

Dneprov, 2014 - Dneprov, E.D. (2014). Obrazovanie i pedagogika dorevolyutsionnoi Rossii: neizuchennye problemy. Spravochnoe posobie dlya issledovatelei [Education and pedagogy of prerevolutionary Russia: unexplored problems. A reference book for researchers]. M.: Marios. 87 p. [in Russian]

Doklad ob uluchshenii tatarskikh shkol, 1913 - Doklad ob uluchshenii tatarskikh shkol v Nizhegorodskoi gubernii [Report on the improvement of Tatar schools in the Nizhny Novgorod province]. N. Novgorod, 1913. Pp. 3-18. [in Russian]

Dyugi, 1908 - Dyugi, L. (1908). Konstitutsionnoe pravo. Obshchaya teoriya gosudarstva [Constitutional law. General theory of the state]. Moskva: Tipografiya Tovarishchestva I.D. Sytina. 911 p. [in Russian]

Dzhurinskii, 2016 - Dzhurinskii, A.N. (2016). Stanovlenie otechestvennogo pedagogicheskogo obrazovaniya i vklad dinastii Romanovykh v ego razvitie [Formation of domestic pedagogical education and the contribution of the Romanov dynasty to its development]. Khudozhestvennoe obrazovanie $v$ dorevolyutsionnoi Rossii. Sbornik nauchnykh trudov. Sost. V.P. Demin, E.M. Akishina, D.V. Pol'. Rossiiskaya akademiya obrazovaniya, Otdelenie obrazovaniya i kul'tury. M.: FGBNU "IKhOiK RAO". Pp. 8-38. [in Russian]

Episkop Nikanor, 1892 - Episkop Nikanor. Nikolai Ivanovich Il'minskii (Il'minskii N.I. Izbrannye mesta iz pedagogicheskikh sochinenii) [Bishop Nikanor. Nikolay Ivanovich Ilminsky (Ilminsky N.I.Selected passages from pedagogical works)]. Kazan', 1892. Pp. 93-94. [in Russian]

Faizkhanov, 1862 - Faizkhanov, Kh. (1862). Reforma medresa (Islakh madaris) [Reform of madras (Islam Madaris)]. Perevod I.F. Gimadeeva. SPb. [Electronic resource]. URL: http://www.idmedina.ru/books /school-book/1297 (date of access: 19.10.21). [in Russian]

Feonychev, 2019 - Feonychev, V.V. (2019). Sistema prosveshcheniya nerusskikh narodov v period kontrreform Aleksandra III [The system of enlightenment of non-Russian peoples during the counter- 
reforms of Alexander III]. Agrarnaya nauka i obrazovanie na sovremennom etape razvitiya: opyt, problemy i puti ikh resheniya. Ul'yanovsk. Ul'yanovskii gosudarstvennyi agrarnyi universitet im. P.A. Stolypina. Pp. 399-404. [in Russian]

Filimonov, 1893 - Filimonov, D.F. (1893). O Nikolae Ivanoviche Il'minskom [About Nikolai Ivanovich Ilminsky]. Kazan', 12 p. [in Russian]

Filippova, 1963 - Filippova, L.D. (1963). Iz istorii zhenskogo obrazovaniya v Rossii [From the history of women's education in Russia]. Voprosy istorii. 2: 209-218. [in Russian]

Firsov, 1869 - Firsov, N.A. (1869). Inorodcheskoe naselenie prezhnego Kazanskogo tsarstva v novoi Rossii do 1762 g. [Non-Russian population of the former Kazan kingdom in new Russia until 1762]. Kazan'. 448 p. [in Russian]

Ganelin, 1950 - Ganelin, Sh.I. (1950). Ocherki po istorii srednei shkoly v Rossii vtoroi poloviny XIX veka [Essays on the history of secondary schools in Russia in the second half of the 19th century]. Pod red. N.G. Kazanskogo. M.: Uchpedgiz, 274 p. [in Russian]

GARF - Gosudarstvennyi arkhiv Rossiiskoi Federatsii [The state archive of the Russian Federation].

Islakh madaris, 1862 - Islakh madaris - reforma prosveshcheniya [Islam Madaris - the reform of education]. SPb., 1862. 54 p. [in Russian]

Ivanova, 2016 - Ivanova, I.P. (2016). Realizatsiya politiki v oblasti obrazovaniya dlya nerusskikh narodov $\mathrm{v}$ dorevolyutsionnoi Rossii na rubezhe XIX-XX vv. (na primere Chuvashskogo kraya) [Implementation of educational policy for non-Russian peoples in pre-revolutionary Russia at the turn of the XIX-XX centuries. (on the example of the Chuvash region)]. XX vek v istorii Rossii. Grazhdanstvennost' i patriotizm naroda v gody velikikh potryasenii i mirnogo stroitel'stva. Sbornik statei. Cheboksary: Chuvashskii gosudarstvennyi universitet im. I.N. Ul'yanova. Pp. 243-250. [in Russian]

Iz Doklada predsedatelya osobogo soveshchaniya, 1905 - Iz Doklada predsedatelya osobogo soveshchaniya po voprosam obrazovaniya vostochnykh inorodtsev tainogo sovetnika A.S. Budilovicha Ministru narodnogo prosveshcheniya V.G. Glazovu s izlozheniem khoda raboty i resheniya soveshchaniya [From the Report of the Chairman of the Special Meeting on the Education of Oriental Foreigners, Privy Councilor A.S. Budilovich to the Minister of Public Education V.G. Glazov outlining the course of work and the decisions of the meeting]. 15 avgusta 1905 goda. Trudy Osobogo Soveshchaniya po voprosam obrazovaniya vostochnykh inorodtsev. SPb., 1905. S. VI-IX, XII-XIV, XXI-XXII, XXXVI-XXXIX, XL-XLII, LI-LII, LIII. [in Russian]

Klarin, 1989 - Klarin, V.M., Kamenskii, Ya.A., Lokk, D., Russo, Zh.-Zh., Pestalotstsi, I.G. (1989). Pedagogicheskoe nasledie [Pedagogical heritage]. M.: Pedagogika, 416 p. [in Russian]

Konstantinov, 1947 - Konstantinov, N.A. (1947). Ocherki po istorii srednei shkoly (Gimnazii i real'nye uchilishcha s kontsa XIX veka do Fevral'skoi revolyutsii 1917 goda) [Essays on the history of secondary schools (gymnasiums and real schools from the end of the 19th century to the February Revolution of 1917)]. M.: Gosuchpedizdat. 1947. 247 p. [in Russian]

Kryukova, 2014 - Kryukova, A.A. (2014). Rol' kollegial'nogo popechitel'stva v razvitii obshchego obrazovaniya $\mathrm{v}$ dorevolyutsionnoi Rossii [The role of collegial guardianship in the development of general education in pre-revolutionary Russia]. Gumanizatsiya obrazovaniya. 6: 30-35. [in Russian]

Kulbakhtina, 2017 - Kulbakhtina, A.Z. (2017). Politicheskii kurs gosudarstva v musul'manskom obrazovatel'nom segmente na rubezhe XIX-XX vv.: zadachi, problemy, resheniya [The political course of the state in the Muslim educational segment at the turn of the XIX-XX centuries: tasks, problems, solutions]. Obrazovanie i dukhounaya bezopasnost'. 1: 56-64. [in Russian]

Kuz'min, 1993 - Kuz'min, M.N. (1993). Natsional'naya shkola Rossii: traditsii i sovremennost' v kontekste modernizatsii [National school of Russia: traditions and modernity in the context of modernization]. Trudy instituta natsional'nykh problem obrazovaniya. M.: INPO. 1: 252. [in Russian]

Kuz'min, 1993 - Kuz'min, M.N. (1993). Rossiiskaya pedagogicheskaya entsiklopediya [Russian Pedagogical Encyclopedia]: T. 1. M.: BRE.. Pp. 227-230. [in Russian]

Kuz'min, 2008 - Kuz'min, M.N. (2008). Razvitie gramotnosti naseleniya i modernizatsiya obshchestva [The development of literacy of the population and modernization of society]. Mir obrazovaniya obrazovanie v mire. 2(30): 120-126. [in Russian]

Kuz'min, 2015 - Kuz'min, M.N. (2015). Rossiiskaya modernizatsiya i nekotorye problemy istorizma cheloveka [Russian modernization and some problems of human historicism]. Forum pedagogicheskogo masterstva. Uchebno-metodicheskoe posobie po materialam Vserossiiskogo master-klassa uchitelei rodnykh, vklyuchaya russkii, yazykov 2011-2013 gg. Pod obshch. red. O.I. Artemenko. M.: INPO. 2015. Pp. 7-12. [in Russian]

Lebedeva, 1988 - Lebedeva, R.L. (1988). Sotsial'noe polozhenie uchitelei Rossii v kanun Velikoi Oktyabr'skoi sotsialisticheskoi revolyutsii [Social status of Russian teachers on the eve of the Great October Socialist Revolution]. Pedagogicheskaya intelligentsiya: sotsial'no-politicheskie problem. Mezhvuz. sb. nauchn. trudov Lenin. gos. ped. in-ta im. A.I. Gertsena. L. Pp. 56-61. [in Russian]

Levassera, 1899 - Levassera, E. (1899). Narodnoe obrazovanie v Rossii [Public education in Russia]. Narodnoe obrazovanie $\mathrm{v}$ tsivilizovannykh stranakh. Izdanie O.N. Popovoi. Red. G. Fal'borka i V. Charnoluskogo. SPb., 1898-1899. T. 2. 1899. 264 p. [in Russian] 
L'vov, 1956 - L'vov, K.I. (1956). Bor'ba P.F. Lesgafta za zhenskoe obrazovanie [The struggle of P.F. Lesgaft for female education]. Sovetskaya pedagogika. 6: 39-48. [in Russian]

Naselenie Rossii poslednie 100 let, 1998 - Naselenie Rossii za 100 let (1897-1997). Statisticheskii sbornik [Population of Russia for 100 years (1897-1997). Statistical collection]. M.: Goskomstat Rossii. 1998. 222 p. [in Russian]

Nikol'skii, 1898 - Nikol'skii, N.M. (1898). Nikolai Ivanovich Il'minskii. Ocherk ego zhizni i deyatel'nosti [Nikolai Ivanovich Ilminsky. Sketch of his life and work]. SPb., 108 p. [in Russian]

O vvedenii vseobshchego..., 1995 - O vvedenii vseobshchego nachal'nogo obucheniya [On the introduction of universal primary education]. Zakonotvorchestvo dumskikh fraktsii. 1906-1917 gody: Dokumenty i materialy. M., 2006. [in Russian]

Ocherk razvitiya, 1914 - Ocherk razvitiya zemskogo khozyaistva [Sketch of development of the zemstvo economy]. N. Novgorod: Tipolit. «Nizhegorodskoe pechatnoe delo». 1914. VI. 228 p. [in Russian]

OR RGB - Otdel rukopisei Rossiiskoi gosudarstvennoi biblioteki [Department of manuscripts of the Russian state library]. [in Russian]

Ososkov, 1982 - Ososkov, A.B. (1982). Nachal'noe obrazovanie v dorevolyutsionnoi Rossii (1861-1917) [Primary education in pre-revolutionary Russia (1861-1917)]. M.: Prosveshchenie. 208 p. [in Russian]

Pavlova, 2016 - Pavlova, A.N. (2016). Deyatel'nost' storonnikov N.I. Il'minskogo v podderzhku sistemy prosveshcheniya nerusskikh narodov Vostoka Rossii v nachale XX veka [The activities of the supporters of N.I. Ilminsky in support of the education system of the non-Russian peoples of the East of Russia at the beginning of the XX century]. XX vek v istorii Rossii. Grazhdanstvennost' i patriotizm naroda v gody velikikh potryasenii i mirnogo stroitel'stva. Sbornik statei. Cheboksary. Chuvashskii gosudarstvennyi universitet im. I.N. Ul'yanova. Pp. 312-317. [in Russian]

Pavlova, 2017 - Pavlova, A.N. (2017). Opublikovannye i dokumental'nye materialy po istorii razvitiya shkol'nogo obrazovaniya nerusskikh narodov srednego Povolzh'ya v 70-90-kh godakh XIX veka [Published and documentary materials on the history of the development of school education of non-Russian peoples of the middle Volga region in the 70s - 90s of the XIXth century]. Vestnik Chuvashskogo universiteta. 2: 121-128. [in Russian]

Pavlova, 2019 - Pavlova, A.N. (2019). Nauchnye trudy N.I. Il'minskogo po voprosam prosveshcheniya nerusskikh narodov [Scientific works of N.I. Ilminsky on the education of non-Russian peoples]. Vestnik Chuvashskogo universiteta. 2: 112-119. [in Russian]

Pavlova, 2020 - Pavlova, A.N. (2020). Gosudarstvennaya natsional'naya politika v oblasti obrazovaniya narodov Povolzh'ya i Priural'ya vo vtoroi polovine XIX - nachale XX veka [State national policy in the field of education of the peoples of the Volga and Ural regions in the second half of the XIX - early $\mathrm{XX}$ centuries]. Istoricheskii opyt natsiestroitel'stva $i$ razvitiya natsional'noi gosudarstvennosti chuvashskogo naroda. Materialy Vserossiiskoi nauchno-prakticheskoi konferentsii. Cheboksary: Chuvashskii gosudarstvennyi institut gumanitarnykh nauk. Pp. 150-157. [in Russian]

Pervaya perepis' naseleniya - Pervaya perepis' naseleniya v Rossii v 1897 godu [The first population census in Russia in 1897]. [Electronic resource]. URL: https://istoriarusi.ru/imper/pervaya-perepis1897.html (date of access: 29.10.2021). [in Russian]

Petrich, 2019 - Petrich, L.V. (2019). Voprosy prosveshcheniya musul'manskikh narodov v deyatel'nosti organov mestnogo samoupravleniya Yuzhnogo Urala v 1870-1917 gg. I.Z. Shayakhmetova [Issues of enlightening Muslim peoples in the activities of local self-government bodies of the Southern Urals in 1870-1917. by I.Z. Shayakhmetova]. Elektronnyi nauchno-obrazovatel'nyi zhurnal «Istoriya». 8(82): 30. [in Russian]

Pravila o nachal'nykh uchilishchakh, 1913 - Pravila o nachal'nykh uchilishchakh dlya inorodtsev: Utverzhdennye Ministerstvom narodnogo prosveshcheniya 05.06.1913 g. Il'minskii N.I. O sisteme prosveshcheniya inorodtsev i o Kazanskoi tsentral'noi kreshchenotatarskoi shkole [Rules on primary schools for foreigners: Approved by the Ministry of Public Education on 06/05/1913. Ilminsky N.I. About the education system of foreigners and about the Kazan central Epiphany Tatar school]. Kazan', 1913. 79 p. [in Russian]

Pupyshev, 2019 - Pupyshev, I.V. (2019). O roli N.I. Il'minskogo v prosveshchenii narodov Povolzh'ya v kontse XIX - nachale XX veka [About the role of N.I. Ilminsky in the enlightenment of the peoples of the Volga region at the end of the XIX - beginning of the XX century]. Paradigmy rossiiskoi istorii skvoz' prizmu biografistiki. Sbornik trudov Vserossiiskoi nauchnoi konferentsii s mezhdunarodnym uchastiem. FGBOU VO «Chuvashskii gosudarstvennyi universitet im. I.N. Ul'yanova». Cheboksary. Obshchestvo s ogranichennoi otvetstvennost'yu «Izdatel'skii dom «Sreda». Pp. 80-83. [in Russian]

Rasporyazhenie Ministerstva narodnogo prosveshcheniya, 1907 - Rasporyazhenie Ministerstva narodnogo prosveshcheniya «Ob utverzhdenii «Pravil o nachal'nykh uchilishchakh dlya inorodtsev» [Order of the Ministry of Public Education "On the approval of the" Rules on primary schools for foreigners"]. 1 noyabrya 1907 g. № 11. P. 461. [in Russian]

Rasporyazhenie Vremennogo pravitel'stva, 1917 - Rasporyazhenie Vremennogo pravitel'stva «Ob ob"edinenii v tselyakh vvedeniya vseobshchego obucheniya uchebnykh zavedenii raznykh vedomstv v vedomstvo Ministerstva narodnogo prosveshcheniya» [Order of the Provisional Government "On unification 
for the purpose of introducing universal education of educational institutions of different departments into the department of the Ministry of Public Education"]. 3 marta 1917 g. SU. 1917. St. 1014. [in Russian]

RGIA - Rossiiskii gosudarstvennyi istoricheskii arkhiv [Russian state historical archive].

Sabirov, 1982 - Sabirov, S. (1982). Nekotorye materialy iz istorii shkol'nogo obrazovaniya tatarskikh shkol Pil'nenskogo raiona Nizhegorodskoi oblasti. Zapiski kraeveda [Some materials from the history of school education in Tatar schools in the Pilnensky district of the Nizhny Novgorod region. Notes of a local historian]. 1982. [Electronic resource]. URL: http://www.idmedina.ru/books/school-book/1305 (date of access: 19.10.21). [in Russian]

Spasskii, 1900 - Spasskii, H.A. (1900). Prosvetitel' inorodtsev Kazanskogo kraya Nikolai Ivanovich Il'minskii [Nikolai Ilminsky, an educator of foreigners in the Kazan Krai]. Samara, 132 p. [in Russian]

Struchkov, 2021 - Struchkov, A.G. (2021). Etnopedagogicheskie aspekty kontseptsii razvitiya natsional'noi shkoly - istoricheskii ekskurs [Ethnopedagogical aspects of the concepts of the development of the national school - a historical excursion]. Sotsiokul'turnoe razvitie $v$ usloviyakh transformatsii obrazovaniya. Sbornik trudov Vserossiiskoi nauchno-prakticheskoi konferentsii. Yakutsk, 17 aprelya 2021 goda. Kirov: Mezhregional'nyi tsentr innovatsionnykh tekhnologii v obrazovanii. Pp. 37-40. [in Russian]

Tolstoi, 1870 - Doklad ministra Narodnogo Prosveshcheniya D.A. Tolstogo «O merakh s obrazovaniem naselyayushchikh Rossiyu inorodtsev» [Report of the Minister of Public Education D.A. Tolstoy "On measures with the education of foreigners inhabiting Russia"]. (1870). [Electronic resource]. URL: http://inpo-rus.ru/14/ (date of access: 19.10.21). [in Russian]

Trudy Osobogo Soveshchaniya, 1905 - Trudy Osobogo Soveshchaniya po voprosam obrazovaniya vostochnykh inorodtsev [Proceedings of the Special Meeting on the Education of Oriental Foreigners]. SPb., 1905. Pp. VI-IX. XII-XIV. XXI-XXII. XXXVIII-XXXIX. XL-XLII. LI-LII, LIII. [in Russian]

Tserkovnye shkoly, 1903 - Tserkovnye shkoly Rossiiskoi imperii. Statisticheskie svedeniya [Church Schools of the Russian Empire. Statistical information]. SPb., 1903-1916. 138 p. [in Russian]

Tsirkulyar Ministerstva narodnogo prosveshcheniya, 1906 - Tsirkulyar Ministerstva narodnogo prosveshcheniya «Ob utverzhdeniya Pravil o nachal'nykh uchilishchakh dlya inorodtsev vostochnoi i yugovostochnoi Rossii» 31 marta 1906 g. [Circular of the Ministry of Public Education "On the Approval of the Rules on Primary Schools for Foreigners in Eastern and Southeastern Russia" March 31, 1906]. № 6-7. Pp. 267-274. [in Russian]

Vakhterov, 1999 - Vakhterov, V.P. (1999). Vseobshchee nachal'noe obuchenie [Universal elementary education]. Moskva, 77 p. [in Russian]

Volkov, 1986 - Volkov, G.N. (1986). Nravstvennoe vospitanie uchashchikhsya IV-VIII klassov sel'skoi natsional'noi shkoly: Posobie dlya uchitelya [Moral education of pupils of IV-VIII grades of a rural national school: A manual for a teacher]. M.: NII nats. shkol, 105 p. [in Russian]

Zakon «Ob otpuske sredstv», 1908 - Zakon, odobrennyi Gosudarstvennym Sovetom i Gosudarstvennoi Dumoi «Ob otpuske sredstv» [A law approved by the State Council and the State Duma on the Leave of Funds]. 6 iyulya 1908 g. SU 1908. St. 996. [in Russian]

Zubkov, 2012 - Zubkov, I.V. (2012). Raspisanie peremen: Ocherki istorii obrazovatel'noi i nauchnoi politiki v Rossiiskoi imperii - SSSR (konets 1880-kh - 1930-e gody.) [Schedule of changes: Essays on the history of educational and scientific policy in the Russian Empire - USSR (late 1880s - 1930s.).]. M.: Iz-vo «Novoe literaturnoe obozrenie». [in Russian]

Zubov, 2018 - Zubov, V.V. (2018). Stanovlenie i razvitie sistemy obrazovaniya i bor'ba s negramotnost'yu v Rossii v XVIII - pervoi polovine XX vv.: tendentsii, prepyatstviya, itogi [Formation and development of the education system and the fight against illiteracy in Russia in the 18th - first half of the 20th centuries: trends, obstacles, results]. Gumanitarnyi vestnik. 12 (74): 7. [in Russian]

Zvyagintsev, 1918 - Zvyagintsev, E.A. (1918). Polveka zemskoi deyatel'nosti po narodnomu obrazovaniyu [Half a century of zemstvo activity in public education]. 2-e izd. M., 88 p. [in Russian]

\section{К вопросу о реформировании народного образования в Российской империи}

Ольга Ивановна Артеменко а, Светлана Петровна Анзорова b , ", Светлана Алексеевна Москвичева с, Дарья Валерьевна Петрухина а

а Российская академия народного хозяйства и государственной службы при Президенте РФ, Российская Федерация

$\mathrm{b}$ Университет «Синергия», Москва, Российская Федерация

c Российский университет дружбы народов, Москва, Российская Федерация

\footnotetext{
${ }^{*}$ Корреспондирующий автор

Адреса электронной почты: anzorova@inbox.ru (С.П. Анзорова) 
Аннотация. В работе показан объективный характер дореволюционного реформирования школьного образования, диктуемого необходимостью просвещения населения России как непременного условия демократического переустройства общества и его экономического развития. Главной исторической причиной, вызвавшей появление всеобщей школы как нового института социализации в дополнение к уже существующим - семье и церкви, была модернизация. Школа церковного прихода была ориентирована на обучение детей грамоте с целью самостоятельного чтения переводной на родные языки Библии для религиозно-нравственного воспитания учащихся, обеспечивая единство веры. А это означало всеобщий, внесословный характер такой школы. В дальнейшем как важнейший социокультурный институт общества, как институт государственной политики школа свои главные задачи получает от государства с целью модернизации общества, обеспечивая всеобщее обязательное начальное образование. В конце XIX - начале XX веков политические партии и общественно-педагогические организации России предлагали введение всеобщего начального обучения. Однако в дореволюционной России такое реформирование образования не было осуществлено. Советская власть в наследство получила 73 \% населения (старше 9 лет) элементарно неграмотное.

Ключевые слова: школа, реформа, дореволюционная Россия, общество, модернизация, грамотность, финансирование, всеобщее обязательное начальное образование. 